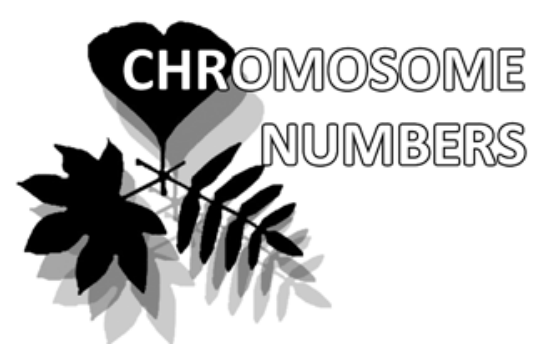

\title{
A karyological study of Micranthes manchuriensis (Engl.) Gornall \& H. Ohba (Saxifragaceae) from Primorsky Krai, Russia
}

\author{
Tomoko Fukuda ${ }^{1 *}$, Marina N. Koldaeva ${ }^{2} \&$ Hiroshi Ikeda $^{3}$
}

Tomoko Fukuda ${ }^{1 *}$

e-mail: fukudatomoko@gmail.com

Marina N. Koldaeva ${ }^{2}$

e-mail: mnkoldaeva@mail.ru

Hiroshi Ikeda ${ }^{3}$

e-mail: h_ikeda@um.u-tokyo.ac.jp

${ }^{1}$ Department of Botany, National

Museum of Nature and Science, Ibaraki

305-0005 Japan

${ }^{2}$ Botanical Garden-Institute FEB RAS,

Vladivostok 690024, Russia

${ }^{3}$ The University Museum, The University

of Tokyo, Tokyo, 111-0033, Japan

* author for correspondence

\begin{abstract}
A B S T R A C T
A karyotype study of Micranthes manchuriensis (Engl.) Gornall \& H. Ohba (Saxifragaceae) from two localities in the Primorsky Kray, Russia, confirmed its chromosome number to be $2 \mathrm{n}=30$. The karyogram of $M$. manchuriensis is formulated as $13 \mathrm{~m}+2 \mathrm{sm}$, with one pair of satellite chromosomes.

K e y w o r d s : chromosome, karyotype, Saxifraga manchuriensis, Russian Far East

\section{P E 3 Ю M E}

Фукуда Т., Колдаева М.Н., ИкеАа Х. Кариологическое исследование Micranthes manchuriensis (Engl.) Gornall \& H. Ohba (Saxifragaceae) из Приморского края, Россия. Кариологическое исследование Micranthes manchuriensis (Engl.) Gornall \& H. Ohba (Saxifragaceae) из Приморского края, Россия показало, что число хромосом у исследованных растений $2 \mathrm{n}=30$. Кариограмма $M$. manchuriensis описывается формулой $13 \mathrm{~m}+2 \mathrm{sm}$, с одной парой сателАитных хромосом.

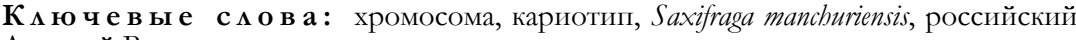
Аальний Восток
\end{abstract}

Micranthes manchuriensis (Engl.) Gornall \& H. Ohba (Saxifragaceae) is a perennial herb, distributed in Russia (Primorsky Krai), northern China, and the Korean peninsula (Zhmylev 1996, Barkalov et al. 2011). It is similar to M. nelsoniana (D. Don) Small in having round to reniform leaves with triangular-deltoid teeth, a paniculate inflorescence, and white petals. It grows on the banks of streams and on moist riverine rocks. Engler (1872) treated it as a variety of Saxifraga punctata L. $(=$ M. nelsoniana). However, it differs from M. nelsoniana in having thick leaves, flowering stems with dense septate hairs, and congested, almost capitate inflorescences (Siplivinsky 1976, Voroshilov 1982, Charkevicz 1989, Webb \& Gornall 1989, Zhmylev 1996, Barkalov et al. 2011, Akiyama et al. 2012). The only chromosome number of Micranthes manchuriensis was reported by Sokolovskaya (1966) as 2n = 30-32.
In June 2015, we collected Micranthes manchuriensis from two localities in Primorsky Krai, Russia (Table 1), and a karyological study was performed to confirm the chromosome number.

Root tips were pretreated in $0.002 \mathrm{M} 8$-hydroxyquinoline solution for 12 hours at $5^{\circ} \mathrm{C}$, fixed with Farmer's solution (glacial acetic acid: $99 \%$ ethanol $=1: 3$ ) and kept in a refrigerator at $5^{\circ} \mathrm{C}$ for more than 10 hours. The root tips were then macerated in $1 \mathrm{~N} \mathrm{HCl}$ for 10 minutes at $60^{\circ} \mathrm{C}$, stained with $1 \%$ aceto-orcein for 10-20 minutes, and squashed. Mitotic metaphase chromosomes were observed for 8 individuals. The karyotype was analyzed for one individual (Fukuda with Koldaeva, No. 2015-BG-1). Voucher specimens are deposited in the Botanical Garden-Institute of the Far Eastern Branch, Russian Academy of Sciences, Vladivostok (VBGI).

Table 1 Locality, somatic chromosome number, and voucher specimen of Micranthes manchuriensis used in this study

\begin{tabular}{llrl}
\hline Locality & Latitude \& longitude & 2n & Voucher \\
\hline Lazovsky District, under waterfall of Elomovsky River & $43^{\circ} 14^{\prime} 45^{\prime \prime} \mathrm{N}, 133^{\circ} 43^{\prime} 05^{\prime \prime} \mathrm{E}$ & 30 & T. Fukuda with V. Bakalin 2015-Elw-2 \\
& & 30 & T. Fukuda with V. Bakalin 2015-Elw-6 \\
& & 30 & T. Fukuda with V. Bakalin 2015-Elw-8 \\
\hline Lazovsky District, along Elomovsky River, ca. 4 km lower & $43^{\circ} 13^{\prime} 45^{\prime \prime} \mathrm{N}, 133^{\circ} 45^{\prime} 34^{\prime \prime} \mathrm{E}$ & 30 & T. Fukuda with V. Bakalin 2015-Elm-1-11 \\
stream from waterfall & & 30 & T. Fukuda with V. Bakalin 2015-Elm-2-10 \\
& & 30 & T. Fukuda with V. Bakalin 2015-Elm-2-13 \\
\hline Vladivostok, Botanical Garden-Institute FEB RAS & $43^{\circ} 13^{\prime 2} 23^{\prime \prime N}, 131^{\circ} 59^{\prime} 39^{\prime \prime E}$ & 30 & T. Fukuda with M. Koldaeva 2015-BG-1 \\
& & 30 & T. Fukuda with M. Koldaeva 2015-BG-2 \\
\hline
\end{tabular}






Figure 1 Photomicrographs of somatic metaphase chromosomes of Micranthes manchuriensis; collected along Elomovsky River, Lazovsky District (Fukuda with Bakalin No. 2015-Elm-1-11). Bar $=5 \mu \mathrm{m}$

The results of the study are shown in Table 2 . All eight of the individuals investigated had a chromosome number of $2 n=30$ (Table 2, Figs. 1 and 2). The chromosomes were 1.1-3 $\mu \mathrm{m}$ long and gradually reduced in size, without clear modality. Satellite chromosomes were observed on the 3rd pair of chromosomes. The chromosome complement was formulated as $2 \mathrm{n}=30=13 \mathrm{~m}+2 \mathrm{sm}$. Although Sokolovskaya (1966) reported chromosome numbers of $2 n=30-32$, we confirmed the chromosome number of Micranthes manchuriensis to be $2 \mathrm{n}=30$.

A variety of chromosome numbers have been reported for Micranthes, ranging from $2 \mathrm{n}=28$ to ca. 88 (see Zhukova $\&$ Petrovsky 1987). Several different chromosome numbers have been reported for $M$. nelsoniana, a close relative of M. manchuriensis: $2 \mathrm{n}=28$ has been reported frequently, from several localities, such as Altai (as "S. punctata s.l.": Sokolovskaya \& Strelkova 1938, 1948 in Zhukova \& Petrovsky 1971), NW Canada (Packer 1964 in Mulligan \& Porsild 1969), NW Taimyr (as "S. aestivalis": Devyatov et al. 1997), Krasnoyarsk (as "S. aestivalis": Funamoto \& Smirnov 2012),
18 is 61118018 48 sa 18

and south Kamchatka (Fukuda et al., in press); $2 \mathrm{n}=30$ was reported for one variety, var. porsildiana (Calder \& Savile) Gornall \& H. Ohba from NE Asia (Zhukova \& Petrovsky 1987; Devyatov et al. 1997), and 2n=26 for another variety, var. reniformis (Ohwi) S. Akiyama \& H. Ohba from Sakhalin (Fukuda et al., in press). These reports suggest that M. nelsoniana includes infraspecific aneuploids, some of which are correlated with morphological differentiation to some extent. It is possible that $M$. manchuriensis arose from a M. nelsoniana-like ancestor through a change in a small number of chromosomes. Such differences in chromosome numbers or aneuploidization, as well as polyploidization appear to be important in the evolution of Micranthes.

\section{ACKNOWLEDGEMENTS}

We would like to acknowledge Dr. V.A. Bakalin for his help with data collection and Dr. D.E. Boufford, Harvard University Herbaria, for his critical reading and checking English grammar of our manuscript.

\section{LITERAT URE CITE D}

Barkalov, V.Yu., A.E. Vrishch, P.V. Krestov \& V.V. Yakubov 2011. Plants of the Ussuri taiga (field guide). Far Eastern Federal University, "Phoenix" Fund, WCS, Vladivostok. 476 рр. [Баркалов В.Ю., Врищ А.Э., Крестов П.В., Якубоов В.В. 2011. Растительный мир Уссурийской тайги: полевой атлас-определитель. ВцаАивосток: ИзА-во АаАьневост. федерацьн. ун-та. 476 с.].

Charkevicz, S.S. 1989. Saxifragaceae. In: Plantae Vasculares Orientis Extremi Sovietici. Vol. 4 (S.S. Charkevicz, ed.), pp. 122-190, Nauka, Leningrad (in Russian). [Харкевич C.C. 1989. Камнеломковые - Saxifragaceae Juss. // Сocy-

Table 2 Arm length, ratio and chromosome type for each chromosome pair (chromosome pair number correspond to those in Fig. 2)

\begin{tabular}{lccccccccccccccccc}
\hline Chromosome pair No. & \multicolumn{2}{c}{$\mathbf{1}$} & \multicolumn{2}{c}{$\mathbf{2}$} & \multicolumn{2}{c}{$\mathbf{3}$} & \multicolumn{4}{c}{$\mathbf{4}$} & & $\mathbf{5}$ & \multicolumn{2}{c}{$\mathbf{6}$} \\
\hline Long arm $(\mu \mathrm{m})$ & 1,50 & 1,50 & 1,34 & 1,42 & 1,26 & 1,14 & 1,22 & 1,13 & 1,22 & 1,25 & 1,09 & 1,21 & 1,00 & 0,86 & 1,07 & 0,80 \\
Short arm $(\mu \mathrm{m})$ & 1,47 & 1,40 & 1,07 & 1,02 & 0,71 & 0,57 & 0,97 & 0,95 & 0,88 & 0,86 & 0,56 & 0,64 & 0,80 & 0,72 & 0,85 & 0,84 \\
Total length $(\mu \mathrm{m})$ & 2,96 & 2,90 & 2,40 & 2,43 & 1,97 & 1,71 & 2,19 & 2,08 & 2,10 & 2,11 & 1,65 & 1,85 & 1,80 & 1,58 & 1,92 & 1,64 \\
Arm ratio & 1,02 & 1,07 & 1,26 & 1,39 & 1,77 & 2,02 & 1,26 & 1,20 & 1,39 & 1,45 & 1,96 & 1,91 & 1,24 & 1,19 & 1,25 & 0,95 \\
Chromosome type & $\mathrm{m}$ & $\mathrm{m}$ & $\mathrm{m}$ & $\mathrm{m}$ & $\mathrm{sm}$ & $\mathrm{sm}$ & $\mathrm{m}$ & $\mathrm{m}$ & $\mathrm{m}$ & $\mathrm{m}$ & $\mathrm{sm}$ & $\mathrm{sm}$ & $\mathrm{m}$ & $\mathrm{m}$ & $\mathrm{m}$ & $\mathrm{m}$ \\
\hline
\end{tabular}

\begin{tabular}{lcccccccccccccc}
\hline Chromosome pair No. & \multicolumn{2}{c}{$\mathbf{9}$} & \multicolumn{2}{c}{$\mathbf{1 0}$} & \multicolumn{2}{c}{$\mathbf{1 1}$} & \multicolumn{1}{c}{$\mathbf{1 2}$} & & $\mathbf{1 3}$ & \multicolumn{2}{c}{$\mathbf{1 4}$} & $\mathbf{1 5}$ \\
\hline Long arm $(\mu \mathrm{m})$ & 1,04 & 0,97 & 0,90 & 0,99 & 0,90 & 0,88 & 0,89 & 0,87 & 0,85 & 0,87 & 0,91 & 0,81 & 0,723 & 0,684 \\
Short arm $(\mu \mathrm{m})$ & 0,88 & 0,77 & 0,78 & 0,76 & 0,74 & 0,69 & 0,71 & 0,82 & 0,73 & 0,72 & 0,56 & 0,61 & 0,489 & 0,479 \\
Total length $(\mu \mathrm{m})$ & 1,92 & 1,74 & 1,68 & 1,75 & 1,64 & 1,57 & 1,60 & 1,69 & 1,58 & 1,59 & 1,47 & 1,42 & 1,212 & 1,163 \\
Arm ratio & 1,18 & 1,25 & 1,15 & 1,29 & 1,21 & 1,27 & 1,25 & 1,06 & 1,16 & 1,20 & 1,63 & 1,34 & 1,48 & 1,43 \\
Chromosome type & $\mathrm{m}$ & $\mathrm{m}$ & $\mathrm{m}$ & $\mathrm{m}$ & $\mathrm{m}$ & $\mathrm{m}$ & $\mathrm{m}$ & $\mathrm{m}$ & $\mathrm{m}$ & $\mathrm{m}$ & $\mathrm{m}$ & $\mathrm{m}$ & $\mathrm{m}$ & $\mathrm{m}$ \\
\hline
\end{tabular}


Аистые растения советского Аальнего Востока / отв. реА. С.С. Харкевич. А.: Наука. Т. 4. С. 122-190].

Devyatov, A.G., P.Y. Zhmylev \& A.D. Kozhevnikova 1997. Chromosome numbers of some arctic species of the genus Saxifraga (Saxifragaceae). Botanicheskii Zhurnal 82:122 (in Russian). [Аевятов А.Г., Жмылев П.Ю., Кожевникова А.А. Числа хромосом некоторых арктических видов рода Saxifraga (Saxifragaceae) // Ботанический журнал. T.82, № 1. C. 122].

Engler, A. 1872. Monographie der Gattung Saxifraga L., mit besonderer Berücksichtigung der geographischen Verbältnisse. Mit einer lithographirten Karte. J.U. Kern (M. Müller), Breslau. 292 pp.

Fukuda, T., E. Andreeva, A. Taran, H. Takahashi \& H. Ikeda 2016. Chromosome number of Micranthes nelsoniana (D. Don) Small (Saxifragaceae) in northeast Asia. Caryologia (in press).

Funamoto, T. \& V.S. Smirnov 2012. Chromosome studies in four species of Saxifraga L. (Saxifragaceae) collected in Tuva and adjacent regions, Russia. Chromosome Botany $7: 31-35$.

Mulligan, G.A. \& A.E. Porsild 1969. Chromosome numbers of some plants from the unglaciated central Yukon plateau, Canada. Canadian Journal of Botany 47:655-662.

Siplivinsky, V. 1976. Generies Saxifraga L. species florae URSS e sectione Micranthes (Haw.) D. Don. Novosti Sistematiki Vyschikh Rastenï 13:134-152 (in Russian). [Сипливинский B.H. 1976. Камнеломки (Saxifraga L.) секции Micranthes (Haw.) D. Don ФАоры CССР // Новости систематики высших растений. Т. 13. С. 134-152].

Sokolovskaya, A.P. 1966. Geographic distribution of polyploid plant species (study of the flora of Primorsky krai). Vestnik Leningradskogo Universiteta, Seriya biologicheskaya
1(3):92-106. [Соколовская А.П. 1966. Географическое распространение полиплоидных видов растений (исследование флоры Приморского края) // Вестник Менинградского Университета, серия биологическая. Т. 1, вып. 3. С. 92-106].

Voroshilov, V.N. 1982. Identifer of the plants of the Soviet FarEast. Nauka, Moscow, 672 pp. (in Russian). [Ворошилов B.H. 1982. Определитель растений советского Аальнего Востока. М: Наука. 672 с.].

Webb, D.A. \& R.J. Gornall 1989. Saxifrages of Europe. Christopher Helm, London, 307 pp.

Zhmylev, P.Y. 1996. Rockfoils of the subgenus Micranthes (Haw.) H.G.L. Reichenbach (Saxifraga L., Saxifragaceae). Byulleten' Moskovskogo Obschestva Ispytatelei Prirody, otdel Biologia 101(6):67-77 (in Russian). [Жмылев П.Ю. 1996. Камнеломки подрода Micranthes (Haw.) H.G.L. Reichenbach (Saxifraga L., Saxifragaceae) // Бюлметень Московского общества испытателей природы. ОтАел биологический. Т. 101, № 6. С. 67-77].

Zhukova, P.G. \& V.V. Petrovsky 1971. Chromosome numbers of certain flowering plants of the Wrangel Island. Botanicheskii Zhurnal 56:294-305 (in Russian). [Жукова П.Г., Петровский В.В. 1971. Хромосомные числа некоторых цветковых растений о. Врангеля // Ботанический журнац. Т. 56, № 2. С. 294-305].

Zhukova, P.G. \& V.V. Petrovsky 1987. Karyotaxonomic study of some species of the genus Saxifraga (Saxifragaceae) from northern Asia. Botanicheskii Zhurnal 72:632-640 (in Russian). [Жукова П.Г., Петровский В.В. 1987. Кариотаксономическое изучение некоторых видов рода Saxifraga (Saxifragaceae) из северной Азии // Ботанический журнац. Т. 72, № 15. С. 632-640]. 